\title{
Wild chimpanzees upgraded to endangered species
}

\section{Washington}

As a compromise between the interests of conservationists and biomedical researchers, the US Fish and Wildlife Service announced last week that it will upgrade the status of wild chimpanzees from threatened to endangered. The change will increase protection for chimpanzees by requiring more documentation on their movement. But because the change applies only to wild chimpanzees, and not those in captivity, conservationists say it leaves a huge loophole for the sale of wild-caught chimpanzees to researchers.

Conservationists wanted all chimpanzees classified as endangered to help stop the depletion of wild chimpanzee populations and to control the number which end up in research laboratories. The Humane Society of the United States (HSUS) says the number living in the wild has dwindled to between 150,000 and 200,000.

The HSUS, the World Wildlife Fund, and primatologist Jane Goodall filed a petition with the Fish and Wildlife Service last year requesting the reclassification of the chimpanzee. They identified the international biomedical establishment as "one of the greatest threats to the continued existence of wild chimpanzees", because the demand for the animals for research encourages poachers to capture and sell wild animals. The HSUS estimates that between five and ten chimpanzees die during the capture of every infant.

The United States has been prohibited since 1977 from importing wild-caught chimpanzees under the Convention on International Trade in Endangered Species. But many African countries have not joined the convention or lack the administrative procedures to enforce it, and conservationists claim that wild chimpanzees continue to enter the United States, which contains 80 per cent of the world's captive chimpanzees.

The National Institutes of Health (NIH) oppose reclassification of the chimpanzee, urging that a federally funded study of wild chimpanzees in Africa be completed before a decision was made. Conservationists agree that a systematic field survey is necessary, but have alleged that NIH's request for a study is a delaying tactic, because it could take up to four years to complete. According to George Galasso, chairman of the US Public Health Service AIDS Animal Model Committee, the urgency for conducting an NIH-sponsored study is now gone, but NIH's Department of Research Resources will have to make the final decision to drop the project. Representatives from that office refused to be interviewed.

The AIDS epidemic has heightened concern over the supply of chimpanzees because they are the only animals besides humans which are susceptible to infection by HIV. Five breeding centres in the United States - set up in the late 1970s after trade in chimpanzees was banned house 350 chimpanzees, but are producing less than 50 young chimpanzees for research per year. Out of the total of nearly 1,400 chimpanzees in US biomedical facilities, NIH officials say only about 800 are virusfree. Many were involved in the testing of the hepatitis B vaccine.

Galasso's committee reviews all federally funded research proposals involving chimpanzees to prevent the duplication of experiments, and to maximize their use by sequencing them through experiments, reserving infection with HIV as a final use.

Early proposals for the NIH survey of wild chimpanzees reportedly mentioned the possibility of using wild-caught animals in AIDS vaccine research, if US breeding efforts did not produce enough. NIH has repeatedly denied considering using wild chimpanzees in AIDS research, and Galasso says the number of animals available for AIDS research is adequate. To ensure that NIH keep their word, Congress in the 1989 NIH appropriations bill forbids NIH to buy wild-caught chimps, or to contract with laboratories that do.

Carol Ezzell

\section{Forest defenders awarded 'Nobel'}

\section{Washington}

Some of those in developing countries who are fighting to preserve tropical rainforests have been honoured in the Swedish parliament. Sahabat Alam (Friends of the Earth) of Malaysia and Jose Lutzenberger of Brazil share this year's Right Livelihood Award, better known as the 'alternative Nobel prize'. Unlike their counterparts in the West, members of Friends of the Earth in Malaysia often risk arrest and imprisonment for anti-logging activities.

Especially mentioned in the prize citation is Harrison Ngau, a 28-year-old Kayan, who has led human blockades of logging roads in an attempt to halt destruction of tribal lands in Sarawak. Ngau is under virtual house arrest and is not expected to be allowed to leave Malaysia for the prize ceremony.

Lutzenberger, now 61, worked for a chemical company until 1972 when he resigned to lead a crusade against Brazil's agricultural policies. His efforts helped to increase the World Bank's environmental sensitivities and fathered the Brazilian environmental movement. Lisa Perlman

\section{More funds for forest research}

\section{London}

THE international effort to reduce tropical deforestation and the associated environmental degradation was speeded up last week when external donors of aid to developing countries agreed to double spending on forestry research by 1995 .

Bilateral and multilateral donors, development banks, non-governmental organizations and researchers met near London to consider the report of an international task force on tropical forestry research, set up in February. The meeting endorsed most of the report's recommendations, including a call for an increase in funds for forestry research from the present level of about $\$ 50$ million to $\$ 100$ million annually. The report says that international expenditure in support of forestry development has roughly doubled over the past five years to about $\$ 1,000$ million, but research expenditure is still only 5 per cent of that. Drastic action is needed to raise the amount of research, says George Holmes, chairman of the task force. The problems which need to be tackled are enormous and the knowledge of how to deal with them is poor.

The report recommends expansion of research in five priority fields: trees in farming systems and watershed management; natural forest ecology and management; tree breeding and improvement; utilization and marketing; and policy and socio-economic issues.

This research could improve the productivity of trees and significantly increase supplies of fuel, fodder and other goods, says the report. This could benefit some of the 120 million people in the Sahelian and Himalayan regions who rely on trees for those products and some of the 3,000 million people who will face shortages of fuelwood by the turn of the century.

To plan and coordinate the research, the task force recommends the formation of an independent research council. But at the meeting last week, that recommendation was rejected. Instead, a forestry unit will be attached to the international coordinating body, the Consultative Group for International Agricultural Research, to help donors, national bodies and research establishments in evaluating priorities, mobilizing support, focusing research and exchanging information.

The absence of any international focal point at present compounds the problems caused by the state of national research strategies, which, says Holmes, are mostly appallingly bad. The task force report says that more political awareness of the issues and secure funding are needed.

Christine McGourty 